DOI

\title{
РОЛЬ ЛЕКЦІЇ У НАВЧАЛЬНОМУ ПРОЦЕСІ ДИСЦИПЛІНИ “ОРГАНІЗАЦІЯ ТА ЕКОНОМІКА ФАРМАЦІЇ” У СИСТЕМІ НОВІТНІХ ЦІЛЙ ВИЩОЇ ФАРМАЦЕВТИЧНОЇ ОСВІТИ
}

Н. В. Шолойко

Національний медичний університет імені О. О. Богомольця

\section{THE ROLE OF LECTURE IN THE EDUCATIONAL PROCESS OF DISCIPLINE “ORGANIZATION AND ECONOMICS OF PHARMACY” IN THE SYSTEM OF NEW GOALS OF HIGHER PHARMACEUTICAL EDUCATION}

\author{
National Medical University by O. O. Bohomolets
}

\begin{abstract}
У статті на основі опрацювання Концепції розвитку фармацевтичного сектора галузі охорони здоров’я України на 2011-2020 роки графічно виокремлено 4 основні цілі фармацевтичної освіти і на їх основі актуалізовано поняття “лекція” у сучасному викладанні дисципліни “Організація та економіка фармації” для майбутніх провізорів.
\end{abstract}

Based on the Concept of pharmaceutical sector development as a healthcare branch of Ukraine for 2011-2020 study, the article presents graphically highlighted 4 main aims of pharmaceutical education and on their basis an updated concept of "lecture” in the modern conditions of teaching the discipline "Organization and Economics of Pharmacy" for future pharmacists.

Вступ. Стратегічними завданнями реформування вищої освіти в Україні є трансформація кількісних показників освітніх послуг у якісні. Цей процес має певні відмінності щодо галузей народного господарства, для яких здійснюється підготовка фахівця, однак характеризується і певними спільними засадами: по-перше, це національна ідея вищої освіти, зміст якої полягає у збереженні і примноженні національних освітніх традицій; по-друге, розвиток вищої освіти повинен підпорядковуватись законам ринкової економіки - закону розподілу праці, закону змінності праці та закону конкуренції, оскільки економічна сфера є винятково важливою у формуванні логіки суспільного розвитку; по-третє, розвиток вищої освіти треба розглядати у контексті тенденцій розвитку світових освітніх систем [1].

У Законі України “Про вищу освіту” сказано: “Вища освіта забезпечує фундаментальну наукову, професійну та практичну підготовку, здобуття громадянами ступенів вищої освіти відповідно до їх покликань, інтересів і здібностей, удосконалення наукової та професійної підготовки, перепідготовку та підвищення їх кваліфікації”. Відповідно до цього Закону основними видами навчальних занять у вищих навчальних закладах (ВНЗ) є: лекція; ла-

(c) Н. В. Шолойко бораторне, практичне, семінарське, індивідуальне заняття; консультація [2].

Перебуваючи на шляху гармонізації вітчизняних освітніх програм із європейськими, де є вищою складова самостійного навчання студента, потребує сучасного переосмислення найдревніший вид навчального процесу, а саме - лекція. Підходи до удосконалення цього виду навчання при підготовці провізорів знайдено у працях як метрів фармацевтичної педагогіки (І. Є. Булах, Д. С. Волоха, Б. П. Громовика, Л. Г. Кайдалової, А. А. Котвіцької, С. М. Марчишин, А. С. Немченко, Б. Л. Парновського, В. П. Черних), так і у молодших колег (В. П. Бобрука, Н. П. Ковальської, І. О. Федяк, А. Л. Штробля) [3-9].

Оскільки вітчизняний освітній простір загалом та фармацевтичний зокрема перебувають на етапі запровадження у навчальний процес новітніх освітніх технологій та створення нової системи інформаційного забезпечення освіти, то доцільним є сучасне переосмислення питання актуалізації лекції як форми навчання у контексті вивчення організації та економіки фармації (ОЕФ).

Основна частина. За рекомендаціями Всесвітньої організації охорони здоров’я (ВОО3) та Міжнародної федерації фармацевтів (МФФ), сім’я належних практик щодо забезпечення надходження 
до споживача якісних, безпечних, ефективних лікарських засобів (ЛЗ) повинна поповнитися ще однією - Належною практикою фармацевтичної освіти (Good practice of Education Pharmaceutical GPEP). GPEP - це сукупність правил і вимог, дотримання яких забезпечує створення адекватної потребам суспільства системи безперервної фармацевтичної освіти і розвиток післядипломної спеціалізації фармацевтичних фахівців [4, 10].

У пояснювальній записці до проекту GPEP BOO3 та МФФ наголошують, що фармацевтичні фахівці здійснюють свою діяльність у різних областях у відповідь на динамічний розвиток пріоритетних напрямів і потреб суспільної охорони здоров'я на місцевому, національному, регіональному і міжнародному рівнях. У межах цього контексту магістри і бакалаври фармації - експерти призначення ліків при лікуванні хвороби і сприяння зміцнення здоров'я. Ця експертиза, в найширшому сенсі, включає підготовку, постачання, контроль і гарантію бажаних результатів використання ліків, починаючи від розробки ЛЗ до використання їх хворими при амбулаторному і стаціонарному лікуванні [10].

Тому у відповідь на заклик ВООЗ та МФФ у Концепції розвитку фармацевтичного сектора галузі охорони здоров'я України на 2011-2020 роки (затвердженої наказом МОЗ України від 13.09.2010 p. № 769 зі змінами, внесеними наказами МОЗ від 30.09.2013 р. № 843 та від 27.03.2013 р. № 242) прописано 4 основні цілі фармацевтичної освітньої діяльності [11]:

- створення умов для розвитку осіб, які обрали професію провізора, та творчої їх самореалізації, виховання покоління людей, здатних ефективно працювати й навчатися упродовж життя, оберігати й збільшувати цінності національної фармацевтичної науки, культури і громадянського суспільства, розвивати й зміцнювати суверенну, незалежну, демократичну, соціальну та правову державу як невід’ємну складову європейської та світової спільноти;

- відтворення інтелектуального потенціалу держави, формування моральних принципів та норм поведінки осіб;

- забезпечення фармацевтичної галузі України висококваліфікованими фахівцями, які можуть успішно працювати в умовах перехідної економіки, реального професійного й міжнародного оточення, що постійно змінюється;

- зростання якісного професійного рівня підготовки спеціалістів з орієнтацією на міжнародні освітні стандарти за рахунок першочергового вдосконалення змісту та форм фармацевтичної освіти, що приведе до підвищення якості послуг у фармацевтичній галузі.

На рисунку 1 графічно зображено означені цілі у вигляді площин, які перетинаються, оскільки лише при їх комплексному забезпеченні можна підготувати “провізора семи зірок”.

Отже, кожен ВН3 III-IV рівнів акредитації, який видає дипломи про фармацевтичну освіту, сертифікат про присвоєння (підтвердження) звання провізора-спеціаліста або проводить передатестаційні цикли за провізорськими спеціальностями для присвоєння (підтвердження) кваліфікаційної категорії, повинен забезпечити виконання означених освітніх цілей. Реалізації кінцевої мети фармацевтичної освіти - підготовці не лише носія спеціалізованих знань, порадника лікаря і хворого, а й свідомого законопослушного громадянина України - повинні підпорядкуватися усі види навчальної діяльності шляхом вдосконалення її змісту та форм.

Щодо вдосконалення змісту, то навчальні плани підготовки провізорів централізовано змінюються як відповідь на бачення профільного міністерства кількісного наповнення компонента фармацевтичної освіти. А от забезпечення якості залежить від конкретного ВНЗ, від функціонування у ньому системи моніторингу якості освіти. Запровадження ширшої автономії ВНЗ сприяє можливості обирання ними тих чи інших новітніх форм навчання, а також суттєвого удосконалення традиційних [4].

Широке коло сучасних дискусій викликає питання місця лекції у системі вищої освіти. Частина педагогів вважає, що лекція $є$ методом навчальної роботи, інші - ототожнюють це поняття з формою навчальної роботи у ВНЗ. Деякі вчені поєднують ці поняття і доводять, що лекція - це “форма організації і метод навчання” [3]. На даний час спостерігається тенденція зменшення ролі лекції у професійній підготовці. На користь цієї тези її носії наводять такі аргументи: сучасні інформаційні технології з використанням комп’ютерних систем витісняють діяльність викладача як лектора; доступність великої кількості джерел інформації дає можливість студентам самостійно здобувати знання, а тому інформаційна функція лекції втрачає актуальність.

Однак огляд педагогічних статей та тез матеріалів науково-методичних конференцій з питань фармацевтичної освіти останніх років перекон- 


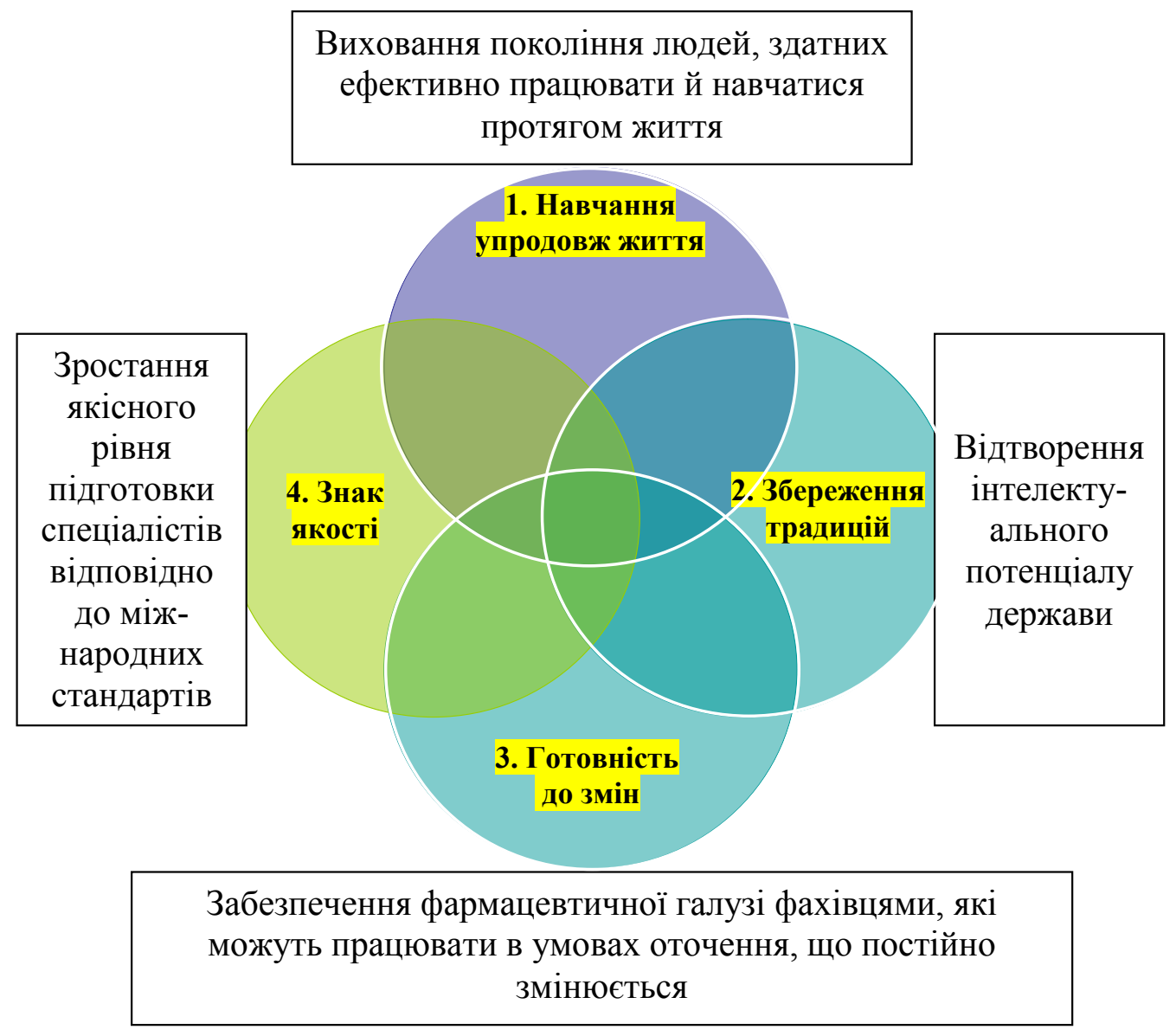

Рис. 1. Основні цілі освітньої діяльності у фармацевтичному секторі галузі охорони здоров’я України.

ливо доводить, що для практичних спеціальностей, діяльність яких зав’язана на частих змінах нормативно-правової бази, лекція залишається домінуючим джерелом інформації для студента. На мою думку, це перш за все стосується вивчення такої базової дисципліни з циклу професійної підготовки студентів спеціальності “Фармація”, як “Організація та економіка фармації”.

У лекційному матеріалі саме з ОЕФ практично на кожній лекції, а особливо з модуля “Організація фармацевтичного забезпечення населення та лікувально-профілактичних закладів”, наявні нові дані та факти, які не лише не опубліковані у підручниках чи навчальних посібниках, а й дуже часто вступили у дію за період від останньої лекції.

Для складання лекцій з ОЕФ лектор - на сучасному етапі становлення законодавчих основ діяльності галузі - займається пошуком достовірних даних та їх інтерпретації, черпаючи їх з монографій, журнальних статей, матеріалів конференцій та, у першу чергу, чинної - на час читання лекції - нормативноправової бази. За таких умов побудови сучасного лекційного курсу ОЕФ дещо на другий план вихо- дить підбір ілюстративного матеріалу, використання риторичних запитань, афоризмів, літературних, політичних, економічних і життєвих прикладів. Однак і ця частина наповнення лекції поряд із викладенням фактів є надзвичайно важливою для мотивації навчально-творчої активності студента. Педагогічна майстерність лектора, яка полягає в розстановці акцентів, покликана сформувати у слухача значення тематики лекції для його майбутньої професійної діяльності та, перш за все, закріпити у нього чітке бачення необхідності навчання упродовж професійного життя. А також завданням лекцій з цього предмета є прищеплення у майбутніх фахівців галузі любові до пізнання, пошуку, обробки інформації на основі використання першоджерел та інформації різних ресурсів. Тому кожна лекція з ОЕФ повинна бути побудована так, щоб, окрім суто інформаційної, виконувати стимулюючу, виховну, розвиваючу, орієнтувальну, роз'яснювальну, переконливу функції, тобто повинна реалізовувати основні освітні цілі, розкриті у першій частині статті.

Висновки: 1. Необхідність реформування системи фармацевтичної освіти України, її удоско- 
налення і підвищення рівня якості, яка зумовлена процесами глобалізації та потребами створення позитивних умов для індивідуального розвитку особистості, є найважливішою соціокультурною проблемою для підвищення якості послуг у фармацевтичній галузі.

2. Лекції з дисципліни “Організація та економіка фармації”, як і увесь сучасний лекційний курс май-

\section{Список літератури}

1. Кобилинська М. І. Основні напрями реформування системи освіти в Україні / М. І. Кобилинська // Нові виміри сучасного світу : матеріали I Міжнар. Інтернет-конф. Мелітополь, 2005. - Т. 1, ч. 1. - С. 87-89.

2. Про вищу освіту : Закон України від 01.07.2014 р. № 1556-18 ВР (в редакції від 04.08.2015 р.). - Режим доступу : http://zakon4.rada.gov.ua/laws/show/1556-18.

3. Кайдалова Л. Г. Професійна підготовка майбутніх фахівців фармацевтичного профілю у вищих навчальних закладах : монографія / Л. Г. Кайдалова. - Х. : НФаУ, 2010. - 364 c.

4. Черних В. П. Моніторинг якості фармацевтичної освіти в Україні / В. П. Черних // Аптека. - 2009. - № 696. Режим доступу : http://www.apteka.ua/article/8881.

5. Волох Д. С. Фармацевтична освіта в Україні: традиції, сьогодення, майбутнє / Д. С. Волох // Аптека. 2003. - № 397 (26). - Режим доступу : http://www.apteka. ua/article/14237.

6. Бобрук В. П. Педагогічні аспекти викладання фармакології та організації економіки фармації із залучен- бутніх провізорів, не втратять своєї актуальності, якщо, зберігаючи кращі традиції вітчизняної фармації, будуть відповідати загальноприйнятим світовим стандартам якості, мотивуватимуть студентів бути готовими до постійних змін та сформують у них стійку потребу навчання упродовж усього професійного життя.

ням інтегрованого підходу / В. П. Бобрук, С. В. Сергєєв, О. Д. Благун // Вісник ВНМУ ім. М. І. Пирогова. - 2012. Т. 16, № 2. - С. 460-463.

7. Ковальська Н. П. Деякі аспекти використання міждисциплінарної інтеграції в лекції для студентів фармацевтичного факультету / Н. П. Ковальська // Медична освіта. - 2015. - № 1. - С. 52-54.

8. Федяк I. О. Особливості викладання предмета “Фармацевтичне правознавство” у сучасній системі підготовки провізорів / І. О. Федяк // Медична освіта. 2014. - № 4. - С. 118-121.

9. Штробля А. Л. Вивчення дисципліни “Організація та економіка фармації” студентами спеціальності “Фармація” / А. Л. Штробля // Медична освіта. - 2015. № 1. - С. 144-147.

10. ВОЗ о роли фармацевта. - Режим доступу : http:// www.apteka.ua/article/12892.

11. Про затвердження Концепції розвитку фармацевтичного сектора галузі охорони здоров’я України на 2011-2020 роки : наказ МОЗ України від 13.09.2010 р. № 769. - Режим доступу : http://www.apteka.ua/ article/57908. 